\begin{tabular}{c|c|c}
\hline \hline & CLIMATE RESEARCH & Published October 18 \\
Vol. 18: 31-37, 2001 & Clim Res & \\
\hline
\end{tabular}

\title{
Regionalization of climate change for the North Sea and Baltic Sea
}

\author{
Corinna Schrum* \\ Zentrum für Meeres- und Klimaforschung, Universität Hamburg, Troplowitzstr. 7, 22529 Hamburg, Germany
}

\begin{abstract}
Using a coupled ice/ocean model, an impact study on the influence of increased westerly winds in the North Sea and Baltic Sea due to strengthening of the polar front was carried out, as part of the German research project KLINO (Modelling inter-annual variability of hydrographic conditions in the North Sea and the Baltic Sea). By means of a simple sensitivity experiment it could be shown that the impact of a positive westerly wind anomaly (i.e. high North Atlantic Oscillation Index, NAO) results in an intensification of the cyclonic circulation in both the Baltic Sea and the North Sea. However, the impact on salt exchange and content is opposite for the 2 shelf seas: exchange between the North Sea and the North Atlantic increases with intensified westerly wind forcing and thus the North Sea salt content increases; for the Baltic Sea, the intensification of westerly winds inhibits exchange with the Kattegat. In combination with the increased doming of the lower layer (i.e. saltier) water in the center of the cyclonic eddies, and thus intensified vertical mixing, an overall decrease of salt content in the Baltic Sea and an erosion of the permanent halocline result. Thus, as it is expected that future climate, under the influence of increased atmospheric $\mathrm{CO}_{2} \mathrm{Con}_{-}$ centration, will lead to an intensification of the NAO, it was concluded that expected anthropogenic climate change will result in a weakening of haline stratification and a decrease in the salt content of the Baltic Sea.
\end{abstract}

KEY WORDS: North Sea $\cdot$ Baltic Sea $\cdot$ Hydrodynamics $\cdot$ Climate sensitivity $\cdot$ Salinity anomalies

Resale or republication not permitted without written consent of the publisher

\section{INTRODUCTION}

The regionalization of climate variability and of expected climate change is one of the main goals of research in shelf sea oceanography. Climate variability has a strong influence on regional shelf seas such as the North Sea or the Baltic Sea. The question therefore arises as to how strongly the system might be affected by expected climate change. Recently some investigations, using forcing conditions from a time slice experiment (Cubasch et al. 1995), have been carried out for the North Sea (Kauker 1999, Langenberg et al. 1999) in order to investigate the influence of predicted climate change on the sea level of the North Sea. 'Time slice experiments' are carried out with high resolution global atmospheric models that are integrated for a relatively short period, using initial and boundary condi-

*E-mail: schrum@dkrz.de tions from long-term integrations with coarse climate models. However, the duration of the 2 time slice experiments each of $5 \mathrm{yr}$ (for present and future climate) is below the time scale for significant climate change ( $30 \mathrm{yr})$, i.e. it lies completely within the time scale of natural variability in the North Sea/Baltic Sea area, and thus it is too short to give reliable estimates about the influence of climate change on the system.

However, from results of global scenario simulations some general ideas about the influence of expected anthropogenic climate change on the climatic forcing conditions for Northern Europe have been developed: deterministic global modelling suggests that strengthening of the polar front, and thus intensification of the North Atlantic Oscillation (NAO, Hurrell 1995) can be expected, as observed by May (1999), which is connected to an increase of the intensity of westerly winds over the North Sea and Baltic Sea. The aim of this paper is therefore to evaluate the influence of changes in the westwind circulation by carrying out a sensitiv- 
ity experiment with a 3D hydrodynamic model in order to give an indication of the regional impact of expected climate change on the North Sea/Baltic Sea system.

\section{METHODS}

\subsection{Numerical model}

The regional ocean model used for this study is the North Sea/Baltic Sea application of the 'Hamburg Shelf Ocean Model' HAMSOM (Schrum 1997, Schrum $\&$ Backhaus 1999). It has been validated intensively for its ability to describe regional and temporal variability of temperature, salinity, sea level and sea ice. For this validation the model has been forced with realistic boundary conditions, taken from the ECMWF reanalysis (Gibson et al. 1996) and integrated for the full re-analysis period 1979 to 1993. The model describes the variability of sea surface elevation, sea surface temperature and salinity with considerable accuracy (Janssen et al. 2001, this issue). To use the model to study the sensitivity of the Baltic Sea and the North Sea to variable climate forcing is therefore well justified.

\subsection{Wind disturbance}

The strengthening of the polar front was approximated by a superposition of a wind field perturbation on top of the actual ECMWF 6-hourly wind fields. The perturbation was assumed to be proportional to the monthly mean wind speed: for the impact study an additional westerly wind speed of $25 \%$ of the monthly mean wind speed was prescribed in a band from $52^{\circ} \mathrm{N}$ to $62^{\circ} \mathrm{N}$.

The impact run was carried out for the period October 1983 to September 1984. The results were compared to the results of the control run with the undisturbed ECMWF wind forcing. To study whether the impact of the perturbation is linear, an additional impact run with negative westerly wind perturbation was performed.

The superposition by vector field addition does not always result in an increase of the wind speed. This is only true for an already positive westwind speed, i.e. for westerly winds. If the undisturbed wind field shows easterly directions, the positive wind field disturbance results in a decrease in wind speed. This is well illustrated by comparing the disturbed and undisturbed wind density distributions for 1 mo with westerly and easterly wind contributions, e.g. February 1984 (Fig. 1). The normalized wind density function is calculated by dividing the wind rose into 72 classes, summing the wind speeds for each respective class and then nor-

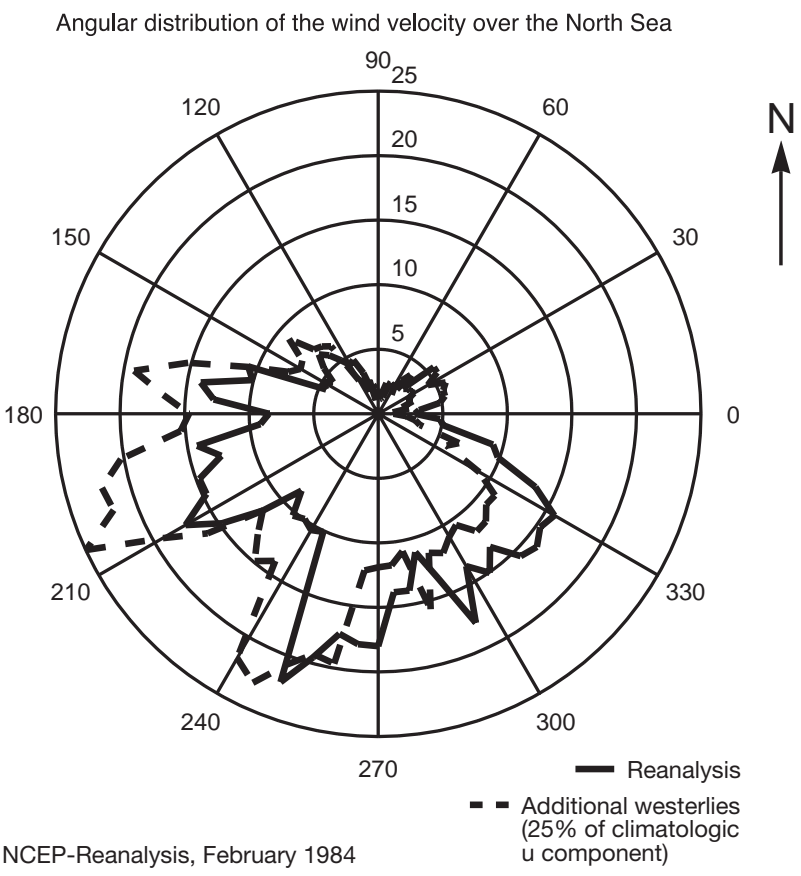

Fig. 1. Wind density distribution for Feb 1984 with (dashed line) and without (solid line) additional westerly wind forcing. Calculated from NCEP reanalysis (Kalnay et al. 1996) by separation of wind direction into 72 different classes and summation of all events for every wet grid point in the North Sea within the respective month. Magnitude normalized by number of events, to give a measure of mean wind speed. Coordinate system is mathematical, i.e. wind from north $=90^{\circ}$

malizing these by multiplication the number of classes divided by the total number of data (for further details see Siegismund \& Schrum 2001, this issue).

The impact on the part of the wind field distribution with prevailing westerly winds is an increase in wind intensity. The opposite is true for the wind density maximum for easterly winds: in this case the wind intensity is reduced by the impact scenario. However, even when easterly winds occur frequently, the region of the North Sea and Baltic Sea is mainly influenced by westerly winds. Thus in summary, it becomes clear that an additional westerly wind will increase wind speed and thus the wind stress and the latent and sensible heat flux, and therefore also evaporation.

\section{RESULTS}

\subsection{Circulation}

The monthly mean circulation for the undisturbed case was mainly cyclonic in the North Sea and the Baltic Sea (e.g. Sep 1984, Fig. 2). This is well known to be the typical circulation for both regions (see review 
by Rohde 1998). Increased intensity of westerly winds results in higher sea level variability in both seas. These changes are caused by changing transports across the borders of the North Sea and the Baltic Sea and thus by changing circulation. To highlight the influence of wind disturbance on regional shelf sea circulation, the monthly mean differences in the volume transport stream function (calculated from the vertical integrated modelled volume transports) for positive and negative westwind anomalies were investigated (Fig. 3). The basis of the investigations is the monthly mean fields for the evaluation period (Oct 1983 to Sep 1984), filtering out short term variability with periods $<1$ mo and thus focussing on the integral effects of the disturbance.

From the comparison of the stream function difference between positive and negative west wind anomaly in North Sea and Baltic Sea, it is obvious that the influence of a westwind intensification results in an intensification of the cyclonic circulation in both shelf seas. The impact has the same order of magnitude $O(0.1 \mathrm{SV})$ for both the North Sea and Baltic Sea (note $\left.1 \mathrm{SV}=10^{6} \mathrm{~m}^{3} \mathrm{~s}^{-1}\right)$, which implies an impact on the Baltic Sea circulation in the order of its monthly circulation. For the North Sea, the impact on circulation is slightly smaller compared to its monthly mean.

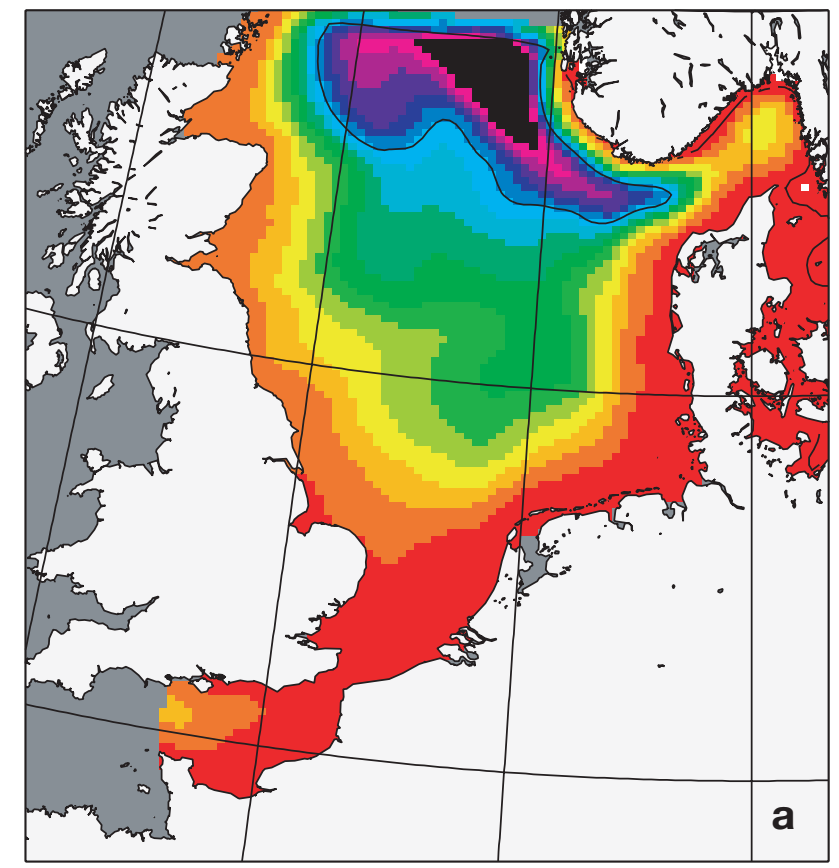

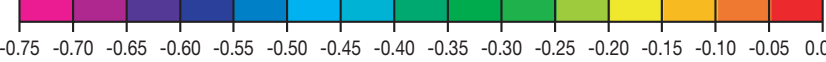

Fig. 2. Monthly mean stream function for (a) North Sea and (b) Baltic Sea, Sep 1984. Unit is SV (i.e. $10^{6} \mathrm{~m}^{3} \mathrm{~s}^{-1}$ )

\subsection{Salinity}

The increase in cyclonic circulation has a remarkably different impact on the North Sea and Baltic Sea with respect to salinity. The regions will therefore be discussed separately.

\subsubsection{North Sea}

The exchange between the North Sea and the North Atlantic is characterised by the cyclonic nature of the North Sea circulation itself: inflow of saline Atlantic water occurs along the British coast, at the western part of the open North Sea boundary, and less saline water leaves the North Sea at the eastern part of the open boundary along the Norwegian coast. Thus, an intensification of the exchange can be expected under the influence of increasing westerly forcing, which is connected to an intensification of the cyclonic circulation (cf. Section 3.1).

The annual mean transports across the open boundaries are presented in Table 1. Even if the annual net exchange across the boundaries (i.e. the net outflow, which is estimated by the net freshwater input to the

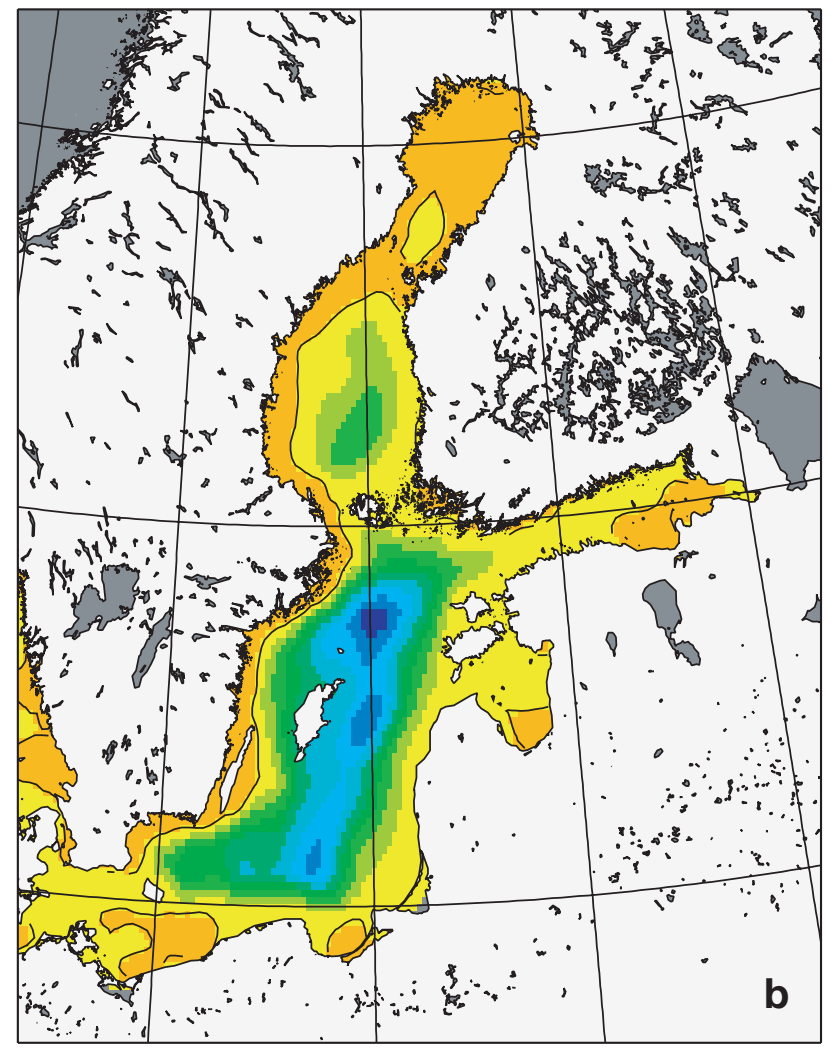

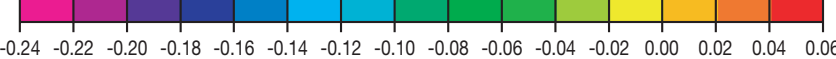




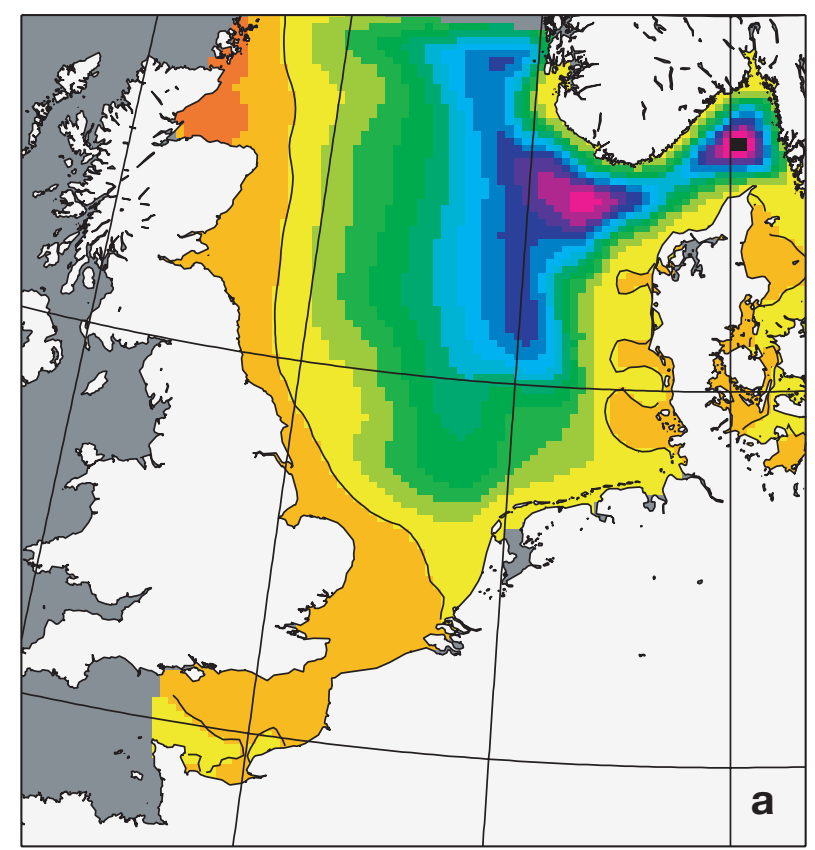

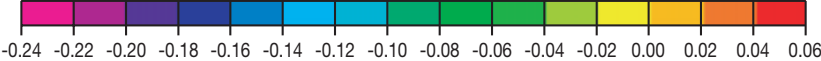

Fig. 3. Difference in monthly mean stream function between cases of high and low westerly wind forcing for Sep 1984: (a) North Sea, (b) Baltic Sea: unit is SV (i.e. $10^{6} \mathrm{~m}^{3} \mathrm{~s}^{-1}$ )

Baltic Sea) is not affected much by increased westerly forcing, there is a considerable impact both on the inflows and outflows. The inflow of saltier North Atlantic water increased strongly with increasing westerly winds, and the outflow of the fresher North Sea water along the Norwegian coast increased as well. Thus, the exchange is intensified in the case of more westerly winds. This results in a difference in mean salinity in the order of 0.065 compared to the run with negative westwind anomaly after 1 yr simulation (Table 1). The difference in salinity is slightly lower after the winter period and increases after the spring

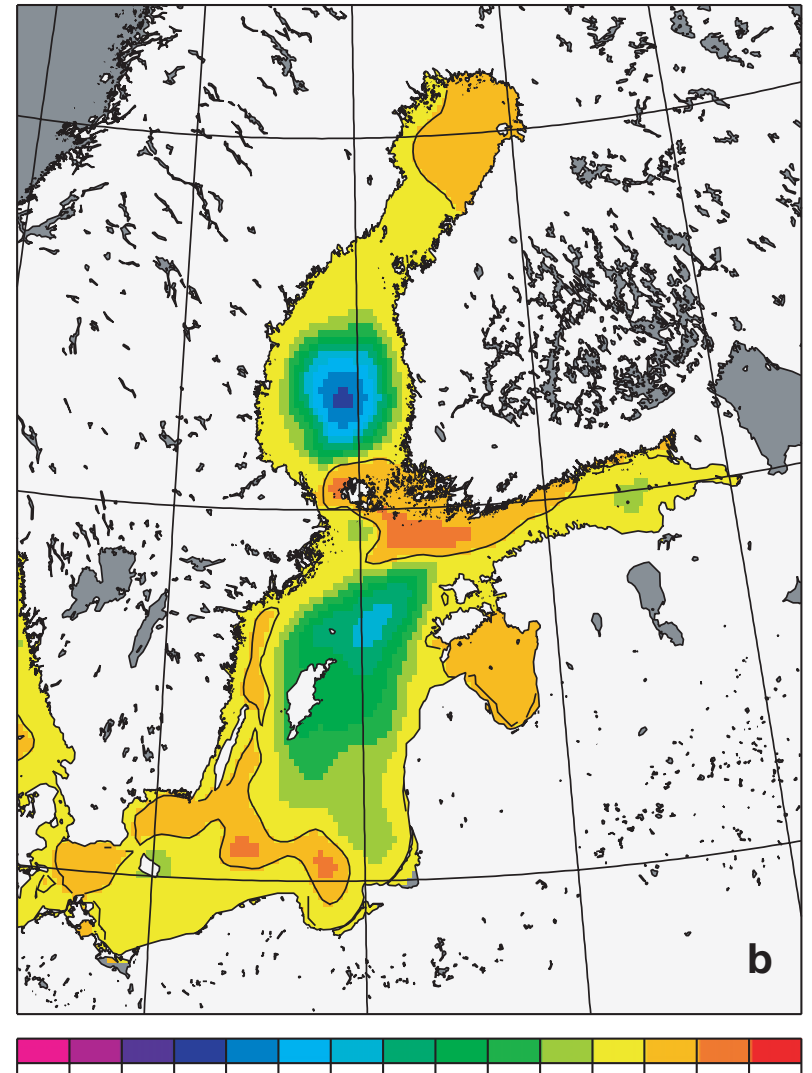

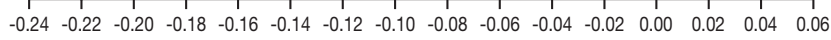

and summer period. This might be caused by interaction with the Baltic Sea (cf. Section 3.2.2): during the spring and summer period the changes in the North Sea and Baltic Sea are in reverse phase, i.e. lower Baltic Sea salinities imply lower fresh water release to the North Sea, and thus higher North Sea salinities. During the autumn and winter period stronger westerly winds result in increased salt content in the Baltic Sea and thus increased fresh water release to the North Sea, which might reduce the effective increase in North Sea salinity caused by the increased exchange with the North Atlantic.

Table 1. Annual mean transport across the boundaries of the North Sea and Baltic Sea and basin mean monthly salinity values, for positive and negative westwind anomaly respectively. NBW = northern North Sea boundary, western part (i.e. inflow area from $3^{\circ} \mathrm{W}$ to $3^{\circ} \mathrm{E}$ and 59 to $20.5^{\circ} \mathrm{N}$ ); $\mathrm{NCC}=$ Norwegian Coastal Current (i.e. outflow regime from $3^{\circ} \mathrm{E}$ to the Norwegian Coast, and 59 to $20.5^{\circ} \mathrm{N}$ ); ECH = English Channel; GB (upper) = transport in first $15 \mathrm{~m}$ across Great Belt; GB (lower) = lower layer transport across Great Belt (15 $\mathrm{m}$ to bottom); SBS = monthly mean salinity anomaly of Baltic Sea; SNS = monthly mean salinity anomaly of North Sea

\begin{tabular}{|c|c|c|c|c|c|c|c|c|c|c|}
\hline & $\begin{array}{c}\mathrm{NBW} \\
10^{6} \mathrm{~m}^{3} \mathrm{~s}^{-1}\end{array}$ & $\begin{array}{c}\mathrm{NCC} \\
10^{6} \mathrm{~m}^{3} \mathrm{~s}^{-1}\end{array}$ & $\begin{array}{c}\mathrm{ECH} \\
10^{6} \mathrm{~m}^{3} \mathrm{~s}^{-1}\end{array}$ & $\begin{array}{c}\text { GB } \\
\mathrm{m}^{3} \mathrm{~s}^{-1} \\
\text { Upper }\end{array}$ & $\begin{array}{c}\mathrm{GB} \\
\mathrm{m}^{3} \mathrm{~s}^{-1} \\
\text { Lower }\end{array}$ & $\begin{array}{l}\text { Sound } \\
\mathrm{m}^{3} \mathrm{~s}^{-1}\end{array}$ & $\begin{array}{l}\text { SBS } \\
\text { Feb }\end{array}$ & $\begin{array}{l}\text { SBS } \\
\text { Sep }\end{array}$ & $\begin{array}{l}\text { SNS } \\
\text { Feb }\end{array}$ & $\begin{array}{l}\text { SNS } \\
\text { Sep }\end{array}$ \\
\hline Positive westwind anomaly & 0.904 & -0.977 & 0.031 & 5408 & -3746 & 7749 & 0.02 & -0.002 & 0.027 & 0.026 \\
\hline Negative westwind anomaly & 0.654 & -0.747 & 0.048 & 10318 & -8668 & 9838 & -0.003 & 0.025 & -0.028 & -0.039 \\
\hline
\end{tabular}


The increase in total salt content is not uniform for the North Sea; pronounced regional structure can be found (Fig. 4). The southern North Sea shows a disproportional increase, by $\sim 1$ for the surface layer, and the northern North Sea shows a slight decrease of salinity of $\sim 0.2$ at the surface, which is caused by intensified mixing of low saline coastal water and saltier North Atlantic water. The calculated relationship between westwind anomaly and salinity anomalies in the North Sea corresponds with earlier analyses. For example, Heyen \& Dippner (1998) found some correlation between westerly forcing and salinity anomalies in the German Bight. It has been previously argued, in a paper on pressure anomalies and their role in hydrographic variations in European Shelf Seas, that longterm salinity anomalies in the North Sea are dominated by oceanic advection anomalies (Dickson 1971). Recent data, from a series of 3 cruises, show that short term salinity changes in the German Bight are dominated by advection anomalies rather than anomalies in freshwater supply (Becker et al. 1999).

\subsubsection{Baltic Sea}

In contrast to the North Sea/North Atlantic system, water exchange between the North Sea/Skagerrak/
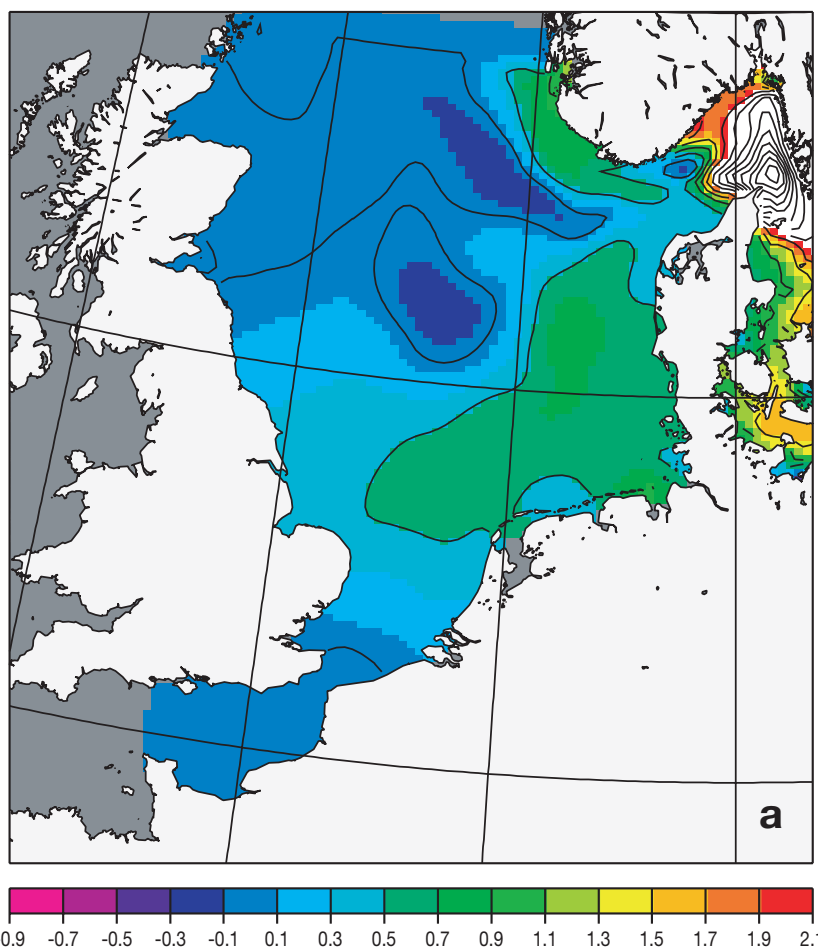

Kattegat system on the one hand and the Baltic Sea on the other can be described by a 2 layer system. In the upper layer there is an outflow of less saline water from the Baltic Sea. This is driven and balanced partly by the freshwater excess due to river runoff and ' $\mathrm{p}-\mathrm{e}^{\mathrm{\prime}}$ (i.e. precipitation minus evaporation) and partly by a salt water inflow in the lower water column (see review by Rohde 1998). The stratified nature of the Baltic Sea exchange implies an opposite sensitivity compared to the North Sea/North Atlantic exchange. The near surface wind driven transport, which directs into the Baltic Sea for westerly wind forcing, is intensified and thus it hinders the outflow of fresher surface water (Table 1). This reduced outflow is connected to reduced sub-surface inflow, resulting in less transport of saline water into the Baltic Sea. Thus, the intensified westerly winds inhibit salt water exchange between the North Sea and Baltic Sea. Total salt content after the full seasonal cycle shows a clear negative anomaly in the case of a positive westwind anomaly. This is consistent with recent statistical analysis of low frequency variability in Baltic Sea salinity, which showed that

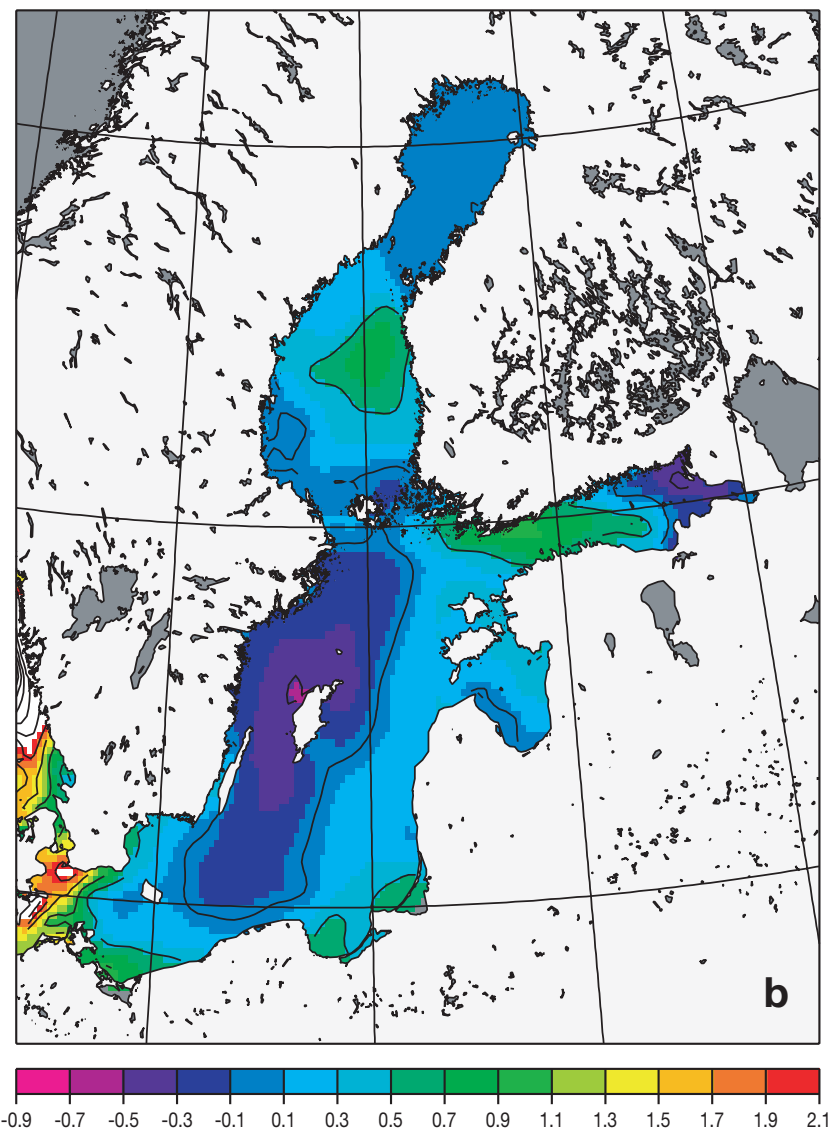

Fig. 4. Difference in sea surface salinity between cases of high and low westerly wind forcing for Sep 1984. (a) North Sea, (b) Baltic Sea. Contour interval $=0.5$ 

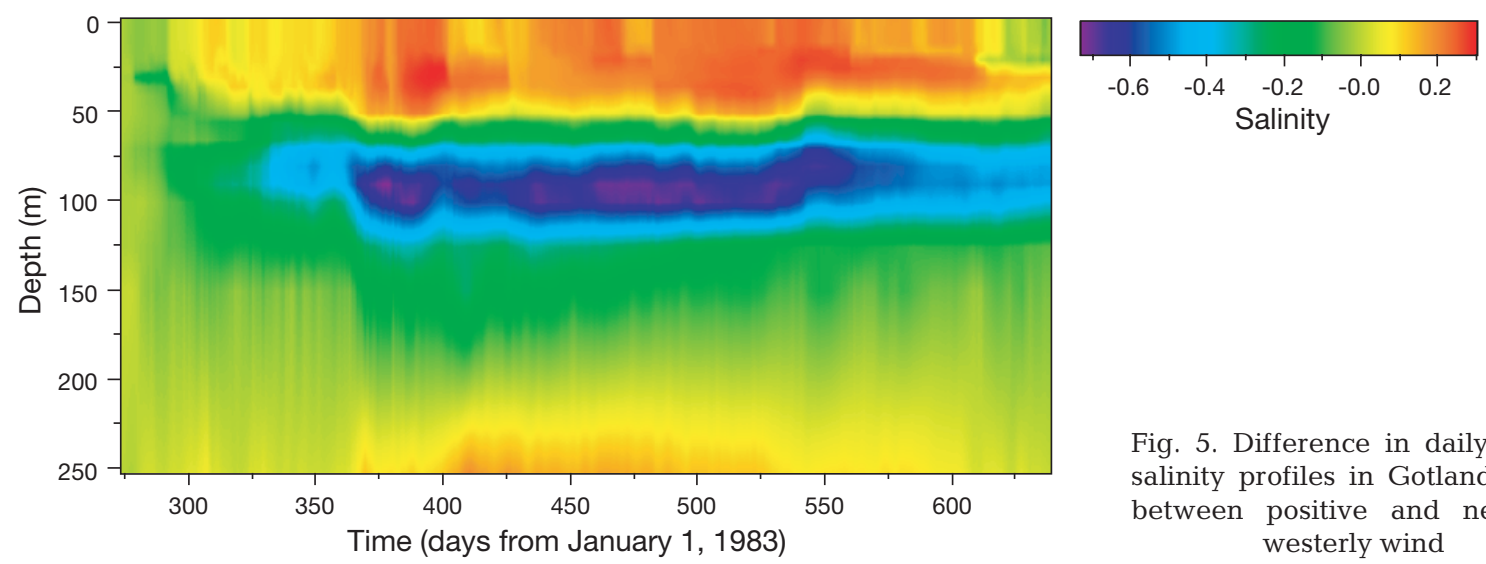

Fig. 5. Difference in daily mean salinity profiles in Gotland Deep between positive and negative westerly wind

lower salinities are correlated with positive anomalies in zonal wind forcing (Laine \& Zorita 1999). These results and the numerical case study discussed here are both inconsistent with the hypothesis expressed by several authors (e.g. Matthäus \& Schinke 1994) that salinity anomalies are mainly caused by major inflows forced by persistent westerly wind forcing. The investigation of the evolution of total salt content in the first half of the hindcast period might suggest an explanation for this discrepancy. In winter, the effect of intensified westerly winds on salt content is the opposite, as the strong barotropic wind-induced circulation is superimposed on the 2 layer baroclinic circulation, and stratification is destroyed by intense vertical mixing. The positive westerly wind anomaly results in higher barotropic wind-induced transport of saltier water into the Baltic Sea, and thus in an increase in total salt content. This is well illustrated by the positive salinity anomaly of the entire Baltic Sea after 5 mo integration for a positive westerly anomaly (autumn and winter period, Table 1). However, after a full seasonal cycle the positive salinity anomaly is completely compensated and turned into a negative salt content anomaly for more intense westwinds.

Cyclonic circulation in a 2 layer system is generally connected with a depression in sea surface elevation and a doming of the subsurface layer in the center of the cyclonic circulation cell, as is well known from oceanographic textbooks. This doming brings colder and saltier sub-surface water to the surface layer, and thus an impact of the intensified cyclonic circulation on the vertical salinity distribution could be expected. This is as well illustrated by comparing the temporal evolution of the difference in salinity profiles at Gotland Deep (central Baltic) for the 2 sensitivity runs (Fig. 5). The difference in sea surface salinity (i.e. salinity in the first $50 \mathrm{~m}$ ) between the 2 runs is up to 0.3 , whereas salinity below the thermocline decreased for more intense westerly winds. Maximum differences up to 0.7 can be found between 75 and $125 \mathrm{~m}$ depth.
The increase in sea surface salinity in the case of anomalous, high westerly winds is inconsistent with the results of Laine \& Zorita (1999), which found that salinity anomalies are coherent across depths and that positive anomalies of the zonal wind component are connected with a decrease in salinity. This discrepancy could be explained by the fact that a positive westerly wind anomaly in North Europe is generally correlated with an increase in precipitation, resulting in decreasing sea surface salinity. This mechanism is not resolved by this simple sensitivity experiment because precipitation anomalies are not considered.

Moreover, comparison of the difference in sea surface salinity illustrates the influence of changes in the large scale wind field on the fine structure of the Baltic Sea system. Changes in the circulation and thus in the strength of upwelling and downwelling events result in a pronounced fine structure for salinity distribution in the Baltic Sea. Local positive as well as negative salinity anomalies up to 1 occur. These local extremes are mainly located in the center of the cyclonic and anti-cyclonic circulation cells. They are caused by enhanced wind-driven circulation and thus intensified convergences and divergences connected with more intense up- and downwelling.

\section{CONCLUSIONS}

Insight into the impact of climate change on the North Sea/Baltic Sea system was achieved by carrying out a model case study on the influence of changing wind conditions. The simulations highlighted the impact of increasing westerly wind forcing on circulation and salinity distribution. The cyclonic circulation in both seas increased under more intense westerly winds and, for the North Sea, results in increased salt content and regional salt anomalies, characterised by a dipolar structure with positive salinity anomalies in the southern North Sea and negative anomalies in the northern 
North Sea. The impact of increasing westerly winds on the Baltic Sea is characterised by reduced salt exchange across the straits and intensified vertical mixing due to increased doming connected with an intensified cyclonic circulation. Sea surface salinity in the Baltic Sea therefore increases under the influence of more westerly winds while both sub-surface and total salt content decrease. The fine structure of the salinity differences calculated for the North Sea and, especially, in the Baltic Sea, clearly illustrate that the local impact of climate change could be the opposite of the overall regional impact. This clearly illustrates the importance of regional differentiation when studying the impact of climate change on a regional scale. Furthermore, it indicates that restraint should be exercised in extrapolating results gained by local statistical analysis of hydrographic variables, influenced mainly by circulation, into regions with insufficient data coverage. This points to the importance of dynamical downscaling (i.e. the use of deterministic, regional models) for studying the regional impact of climate variability and change.

Moreover, this case study highlights the role of advection for salinity, and despite or perhaps due to the simplification of climate variability over the North European Shelf, could provide some valuable hints towards explaining the relationship between salinity and zonal wind forcing, found previously by statistical analysis (e.g. North Sea, Dickson 1971, Heyen \& Dippner 1998; Baltic Sea, Laine \& Zorita 1999).

However, simple sensitivity experiments, such as those carried out here, have only a limited scope. The influence of changes in large scale atmospheric circulation on e.g. air temperature and humidity are not considered here. These will also affect heat and fresh water fluxes and thus cause nonlinear interactions with the differences caused by wind field changes. Quantification of the influence of expected climate change on the North Sea/Baltic Sea, considering all these nonlinear effects, could be achieved by carrying out a downscaling experiment for a longer period, e.g. the study by May (1999), where two 30 yr time slices were calculated, one for the present day and one for the future $2 \times\left[\mathrm{CO}_{2}\right]$ climate. These results need to be used for future impact studies.

Acknowledgements. The study was carried out under the framework of the project 'KLINO' (Modelling climate variability of hydrographic parameters in the North Sea and Baltic Sea). The project was funded by the German Ministry of Science and Education (BMBF) under grant number 03F0185B. I am grateful for the productive cooperation and fruitful discussions within the project and so to the KLINO team: Frank Janssen, Udo Hübner, Jan Backhaus, Eva Bauer, Kurt Duwe, Petra Mahnke, Catrin Pieri and Anneliese Fey.

\section{LITERATURE CITED}

Becker GA, Giese $H$, Isert $K$, König $P$, Langenberg $H$, Pohlmann T, Schrum C (1999) Mesoscale variability in the German Bight. Dtsch Hydrogr Z 51(2/3): 155-179

Cubasch U, Hegerl GC, Hellbach A, Hoeck H, Mikolajewicz U, Santer DB, Voss R (1995) A climate change simulation starting from 1935. Clim Dyn 11:71-84

Dickson RR (1971) A recurrent and persistent pressureanomaly pattern as the principle cause of intermediatescale hydrographic variation in the European shelf seas. Dtsch Hydrogr Z 24:97-119

Gibson R, Kallberg P, Uppala S (1996) The ECMWF ReAnalysis (ERA) project. ECMWF Newsletter 73:7-17

Heyen H, Dippner JW (1998) Salinity variability in the German Bight in relation to climate variability. Tellus 50A: $545-556$

Hurrell JW (1995) Decadal trends in the North Atlantic Oscillation: regional temperatures and precipitation. Science 269:676-679

Janssen F, Schrum C, Hübner U, Backhaus J (1999) Uncertainty analysis of a decadal simulation with a regional ocean model for the North Sea and Baltic Sea. In: Sündermann J, Lenz W (eds) Impact of climate change on the coastal zone. CR SPECIAL 10. Clim Res 18:55-62

Kalnay E, Kanamitsu M, Collins W, Deaven D, Gandin L, Iredell M, Saha S, Withe G, Woollen J, Zhu Y, Chelliah M, Ebisuzaki W, Higgens W, Janowiak J, Mo KC, Ropelewski C, Wang JA, Reynolds R, Jenne R, Joseph D (1996) The NCEP/NCAR 40 Year Reanalysis Project. Bull Am Met Soc $77(3): 437-471$

Kauker F (1999) Regionalization of climate model results for the North Sea. PhD thesis, Universität Hamburg

Laine A, Zorita E (1999) Low-frequency evolution of hydrographic variables in the Baltic Sea and its relationship to the atmospheric circulation. GKSS Report 99/E/14, GKSS, Geesthacht

Langenberg H, Pfizenmayer A, von Storch H, Sündermann J (1999) Storm related sea level variations along the North Sea coast: natural variability and anthropogenic change. Cont Shelf Res 19:821-842

Matthäus W, Schinke (1994) Mean atmospheric circulation patterns associated with major inflows. Dtsch Hydrogr Z 46:321-339

May W (1999) A time-slice experiment with the ECHAM4 A-GCM at high resolution: the experimental design and the assessment of climate change as compared to a greenhouse gas experiment with ECHAM4/OPYC at low resolution. Danish Meteorological Institute. Sci Rep 99-2

Rodhe J (1998) The Baltic and North Seas: a process-oriented review of the physical oceanography. Coastal Segment $\left(20^{\circ} \mathrm{S}\right)$. In: Robinson AR, Brink KH (eds) The sea, Vol 11. Wiley, New York, p 699-732

Schrum C (1997) A coupled ice-ocean model for the North Sea and the Baltic Sea. Sensitivity of North Sea, Baltic Sea and Black Sea to anthropogenic and climatic changes. In: Özsoy E, Mikaelyna A (eds) Sensitivity of North Sea, Baltic Sea and Black Sea to anthropogenic and climatic changes, Nato ASI Series, Kluwer Academic Publishers, Dordrecht, p 311-325

Schrum C, Backhaus J (1999) Sensitivity of atmosphere-ocean heat exchange and heat content in North Sea and Baltic Sea. A comparative assessment. Tellus 51A: 526-549

Siegismund F, Schrum C (2001) Decadal changes in the wind forcing over the North Sea. In: Sündermann J, Lenz W (eds) Impact of climate change on the coastal zone. CR SPECIAL 10. Clim Res 18:39-45 